\title{
Job Opportunity, Attitudes, Perceived Behavioral Control and Intention to Major in Accounting
}

\author{
Paskanova Christi Gainau
}

\author{
Accounting Department, Faculty of Economics and Business, Universitas Pattimura \\ Jl. Ir. M. Putuhena, Kampus Poka, Ambon Maluku - Indonesia \\ paskanova@gmail.com: ${ }^{\text {a }}$
}

\begin{abstract}
This research aims to capture the accounting behavior phenomenon in accounting students at private universities in Manado. This research is developed from the study of Lin \& Fawzi (2006), Zandi et al.(2013), and Odia \& Ogiedu (2013). To find out the inconsistency of these researches, this research focus to study about the students's intention in choosing an accounting program. Partial least square is used to analyze the research model.This study used questionnaires and deep interviewed to collect the data. It reveals that job opportunities deliver positive effects on accounting students's attitudes, and these attitudes affect their intention to select the program. The reputation on higher education institutions on accounting do not determine the students's attitudes to enroll in accounting. Subjective norm do not influence students intention. Perceived behavior control positivelyencouragesthe purpose of choosing the accounting program. These findings designate implications for accounting lecturers to explain the benefits, job opportunities, and temporary accounting issues to students. Management of the accounting department needs to re-design their curriculum; thus, it can drive college students to compete and have fun throughout the learning process. Lecturers are obligated to update their learning methods and include educational characters in the provision of material to increase students's motivation.
\end{abstract}

Keywords: accounting college student; job opportunities; reputation of higher education institution on accountin; partial least square; theory of planned behavior

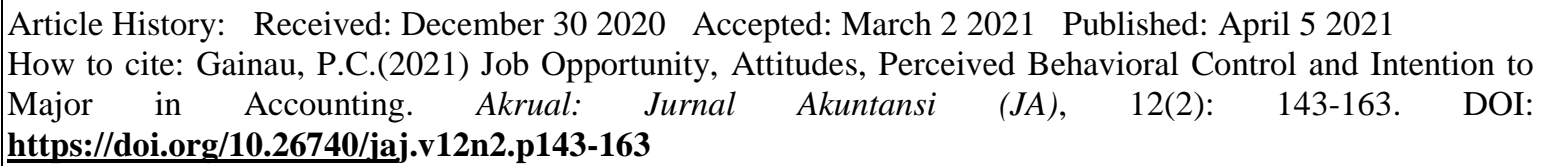

\section{INTRODUCTION}

Learning accounting is interestingly challenging. Dramatic development in technology and the business environment are revolutionizing accounting practices. A significant decline in the number of candidates willing to pursue a career as an accountant is observed abroad - USA, Australia, and Japan. However, in other countries-Brazil, Singapore, and Hong Kong-the opposite has. Another issue is the decrease in the educational qualification of those pursuing an accounting career, contributing to how many talented undergraduate students alter their career choices. This decrease is explained the fact that people believe accounting is an exact science, calculative, humdrum, and uncreative, bringing an unbalanced condition between the traits an individual should have according to the job market and those perceived by society (Hsiao \& Nova, 2016).

Facing the era of the ASEAN Economic Community (MEA), one of the profession recognized in the MRA (Mutual Recognition Agreement), is the accounting 
Gainau. Job Opportunities, Attitudes,Perceived Behavioral.....

services. The MRA is a mutual recognition between ASEAN members of professional services for licensed or certified professionals. It directly implies that the accounting profession is an occupation profession in the current MEA era. Therefore, a massive desire to obtain an occupation to become an accountant among these students is a necessary.

This research is designed to observe accounting students in various private universities and colleges. The phenomena are, in general, the declines of students' willingness to continue degrees in accounting major. It is believed that there are several factors contributing to this situation. This study had an opportunity to interview several undergraduates whose willingness and intentions of studying in accounting are failing. Some of them claimed that it was not their decision to set goals in majoring the subject. Rather, it was determined by their family, friends, and due to job requirements. To consider the important purposes of learning accounting for students's careers in accounting, this study was motivated to examine their motivation and enthusiasm when selecting accounting as their study goal by implementing this study.

A survey, conducted among accounting college students at several campuses in Manado shows that the accounting profession is not the occupation of interest to a college student because of its work complexity. It is inversely proportional to the need for the accounting profession in Indonesia.

The survey result shows the accounting profession is in the second rank $(25.7 \%)$ after entrepreneurs (38.6\%). It is shown Table 1:

Table 1 Survey Result

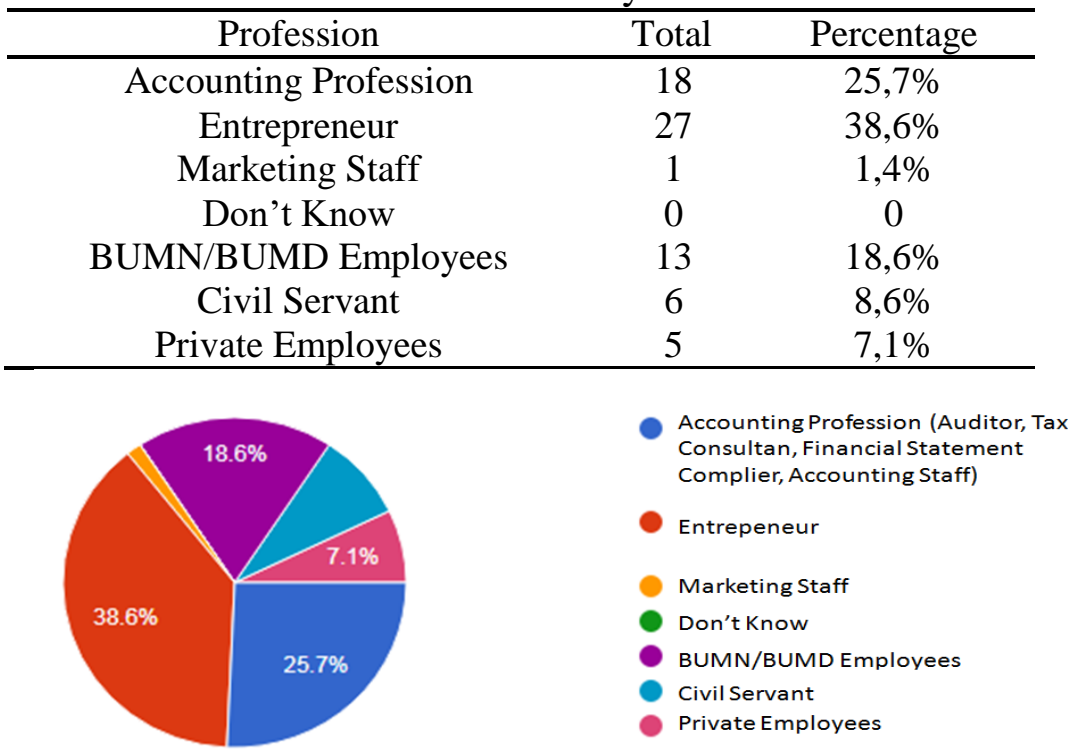

An accounting program allows college students to attrain skills to work as accounting practitioners, businessmen, professionals, and accounting educators. Former researches who focused on studies regarding supporting factors of the intention of students were (Gul 1989). Gul (1989) considers job opportunity as a variable affecting the decision in determining accounting study program. On the contrary, Lin \& Fawzi (2006) believe that job opportunity is not a contributing factor in selecting accounting. The authors identify that personality, referents, and control are significant variables 
influencing the willingness to choose an accounting subject. Furthermore, Kim, Markham, \& Cangelosi (2002) develop a similar method and include job opportunity as one of the variables. The study findings prove that employment chances play important part in choosing study majors, especially accounting. A comparable study was also conducted by Zandi et al. (2013), which is based on a survey focusing on attitudes and referents variables. It points out these two variables hold significant roles in encouraging someone to major in accounting. Odia \& Ogiedu (2013) carried out equivalent research and discovered that employment factors inspire students to choose an accounting study program.

Studies above inconsistently designates job opportunities in the research model. It clarifies that job opportunity is not the primary factor prioritized by a person in deciding accounting subject. One of the reasons is distinct research areas. Therefore, this raises variable consideration according to the research areas.The current research model is derived from Lin \& Fawzi (2006) with adopted modification from Zandi et al. (2013) and Odia \& Ogiedu (2013) to better fit into the context of student's intention to enroll in an accounting program. In Indonesia, the era of industrial revolution 4.0 directly demands individuals to think further about their careers.This study aims to first emphasize research inconsistency that job opportunity is essensial to be considered when selecting accounting study program.

Employment chance in accounting is a motivating factor for someone to major accounting (Gul 1989; Kim et al.(2002); Odia \& Ogiedu, 2013; Hsiao \& Nova, 2016). Furthermore, personality (attitude), referents (subjective norms) and control also affect willingness to choose accounting degree in universities (Lin \& Fawzi, 2006; Zandi et al., 2013). Meanwhile, Kim et al., (2002) figure out the primary reasons for majoring accounting are potential carrer, job opportunities, and tendency towards running a business and projected earnings in the related career. It is in line with Hsiao \& Nova (2016) result that students choose accounting as their focus is influenced by job security, money-making, job availability, creativity, independence, challenging and dynamic environment, and other significant people. On the other hand, some facts confirm that people tend to believe accounting as an exact science, full of calculations, uninteresting, and lack of creativity.

The era of industrial revolution 4.0 also encourages a person to obtain highquality standard of aimed learning goals to further study in universities. One of the main factors easily identified is reputation of university (Ahmad, 2015; Spekman \& Carraway, 2006). Universities with an excellent rating can attract students to enroll in their study programs (Sathapornvajana \& Watanapa, 2012), including accounting. On the contrary, the contingencies to pursue further learning at universities and colleges are challenging for most people. Therefore, universities and colleges ranking is not something to be concerned. Students and parents tend to contemplate the tuition fee. Hence, the researcher aims to emphasize whether the reputation of higher education institutions affect the students choice.

Research of Spekman \& Carraway (2006) and Ahmad (2015) discover that an excellent reputation impacts student's satisfaction. In recent years,ranking system has been developed for various domains of universities's quality. Ranking shows the 
Gainau. Job Opportunities, Attitudes,Perceived Behavioral.....

reputation of campus. These are used in publicity to attract students and informed endowments or to increase enrollment. Prospective graduate school applicants were by advisors to prioritize the rankings in deciding departments and programs for application (Spekman \& Carraway, 2006). It means university reputation is a main indicator of society to choose a campus.

However, the chance to study at higher education institution is a problematic matter for most people. Therefore, higher education institution ranking is not a part of their consideration. Students tend to consider the tuition fee.This research also adds the reputation of higher education institution as a new variable.

Current research aims to examine job opportunities, attitudes, subjective norms, perceived behavioral control, and reputation of higher education institution to student's intention to choose accounting. Unlike former research, the respondents were all regular college students. In this research, some of the respondents are on-job students. These students have worked in various departments such as government and tourism sectors, and become entrepreneurs. Additionally, position and monthly wages have been earned during working in a company. It is interesting to investigate what factors boosting them to choose an accounting program. Generally, one selects to learn accounting is because one is interested in promising job opportunities (Kim et al., 2002; Hsiao \& Nova, 2016). The contribution of this research is to provide information for accounting department in a private higher education institution in regards to prepare and fulfill optimal undergraduate students' needs.

\section{Theory of Planned Behavior (TPB)}

Theory of Planned Behavior (TPB) is a model and approach which is applied to study the relationship between cognitif variables and intentions. In this research, TPB examines the relation of antecedent variables to the student's choice when selecting study program.

TPB is an intention-based model which was developed by Ajzen and Fishbein in 1980. It explains the association between intention and the particular behavior of someone. Intention indicates how someone does efforts and show spesific behavior (Ajzen \& Driver, 2018). TPB postulates three independent predictors, i.e., attitude, subjective norms, and perceived behavior control. Attitude refers to how one evaluates one's behavior, which is, beneficial or not. Subjective norms associate with social pressure which affects an individual to behave and not. Perceived behavior control points out easiness and difficulty, which control behavior, where the' higher' behavior-controlled perception, the stronger behavior-considered (Ajzen \& Driver, 2018).

TPB has been implemented in various types of researches to predict behavior and intention. Scott Hunsinger \& A. Smith (2017) study factors that influence the purpose of Information System Undergraduates to pursue IT certification. In his analysis, all three TPB constructs were signficant in predicting Behavioral Intention. Arifatul Husna, Zainol, Zakiyah, \& Adura (2010) predict students's intention to be an entrepreneurs. van Hooft, Born, Taris, van der Flier, \& Blonk (2004) investigate job-seeking behavior and its predictors among employed and unemployed. The findings revealed that the attitude - the intention - behavior relationship was more robust in the unemployed group than the employed group. Lin \& Fawzi (2006) discover three determinant 
factors of business students' intentions, i.e., personal, referents, and control. The research model is as follow:

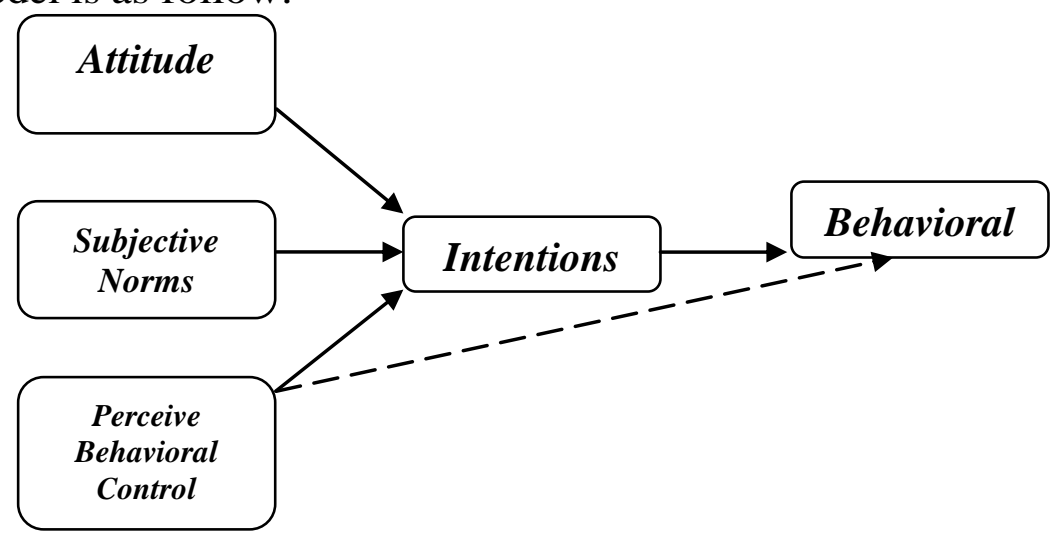

Figure 1.Theory of Planned Behavior (Ajzen, 1992)

The current study uses the TPB model and adds two new variables i.e. job opportunity and reputation of higher education institution on accounting. Additionally, variables are considerable for undergraduates when enrolling at college and universities. While university reputation become moderate variable that can interrupt the influence of students attitude and willingness to choose accounting program. TPB model studies which variables significantly determine college student's purpose when deciding an accounting program. Based on the statement above, this study has hypothesized as follows:

\section{Job Opportunity}

The job opportunity is defined as an employment prospect provided in the future. One factor that influences students to take an accounting program isa working opportunity. Generally, accounting provides adequate job opportunities and high earning for people (Gull 1989; Kim et al., 2002); Odia \& Ogiedu 2013); Hsiao \& Nova 2016).

Kim et al., (2002) and Widowati \& Surjawati (2015) perceive the main reason for a student to pick an accounting program was job availability (accountants are hired most of the time). Undergraduates conceive that after accomplishing their studies, companies will offer jobs.

Saemann \& Crooker (1999) investigate student awareness of the profession and its effect on an accounting major. The results indicate that perceptions of precision and thoroughness in the domain and the heavy workload in the introductory course discourage creative personalities from pursuing an accounting major. However, this negative point of view forces college students to develop their creativity, especially cognitive ability. This aspires them to major in accounting. Even though students think negatively of the accounting profession, it does not change their decision to enroll in an accounting program.

College student realizes a perspective and promising job in accounting which inspire them to have the outcome evaluation positively. It is in accordance with Odia \& Ogiedu, 2013) finding that factors affecting undergraduates to choose accounting are long term salary possibilities, prestige, job security, and starting salary. 
Gainau. Job Opportunities, Attitudes,Perceived Behavioral.....

Lin \& Fawzi (2006) have also reveals that high payment, broad job opportunities and high social status in community perception are considered as other factors. The factors mentioned above are represented by one variable i.e. job opportunity. Both positive and negative perception support university student's attitudes to apply in an accounting program. College students tend to recognize negative perception as the opportunity to increase their capability. Therefore, the hypothesis is as follow:

$\mathrm{H}_{1}$ : Job opportunity positive significantly affect student attitude to choose accounting program.

\section{Course Pursuit Attitudes}

Icek Ajzen \& Thomas J. Madden (1986) define attitude as an individual evaluation of favorableness and unfavorableness. It is a belief of a person that occurred from involving particular behavior. Further, it is determined through behavioral belief and outcome evaluation of such action (Bobek and Hatfield, 2003). Different attitudes caused is similar behavior. A positive attitude about accounting will generate the right intention to choose and study accounting. On the contrary, a negative attitude will yield a negative result, which is students will not prioritize accounting as their focus.

Lin \& Fawzi (2006) discover that student attitudes (personal perception) influence their intention to major in an accounting program. Furthermore, Hooft, Born, Taris, \& Flier, (2006) as certain that job pursuit attitude influence the intention to seek a job. Also, Saemann \& Crooker (1999) state that students choose accounting program because they are interested in it. It indicates that their perception will form their attitude, including like-toattitude. It enhances their intention to prefer an accounting program. It forces them to survive and enjoy the learning process throughout the semester.

Attitude holds important influence on the behavioral intention of both male and female students in universities to enlist themselves in accounting programs (Zandi et al,. 2013).This individual attitude is shaped by student's perceptions. If in a period, students receive positive information about accounting, they are encouraged to major accounting. Conversely, if negative information received, they will be discouraged from accounting. However, Saemann \& Crooker (1999) reveal that negative information (perception) forced undergraduates to increase their creativity, especially cognitive ability. Hence, this concern is about how much information students acquire before deciding university major, particularly accounting.

Zandi et al. (2013) state the amount of information on accounting is positively correlated with the attitude. Later, the attitudes and amount of valuable accounting information are positively correlated with intention to enroll. However, others address that attitudes do not predict preferences (Bae \& Kang, 2008).

$\mathrm{H}_{2}$ : Attitude positively and significantly affects student's intention to major accounting.

\section{Reputation of Higher Education Institution on Accounting}

Ahmad (2015) find the reputation of higher education institution as a factor affect student's chice when determining major in universities. It appears as a quality in society. It can measure how good an institution is. Most of the respondents emphasized that the image and reputation of higher education institution in one of the main factors which influence student's decision to study further. What is more, Sathapornvajana \& Watanapa (2012) reviewed the factors affecting a student's intention to choose an IT program. The findings reveal that the school reputation is the most crucial attribute affecting 
the behavioral preferences of IT schools. It indicates that a reputation is a factor encouraging students to apply for schools and universities.

Regarding enrollment in accounting program, people will contemplate with the reputation of higher education institution. It affects students' attitudes when selecting this subject. There are several cases have occurred in which positive perceptions of students about accounting help them decide on it, but once they find out that accreditation status is unsatisfactory, their motivation is discouraged. Consequently, they will prefer other university. Accreditation status hinders and meddles the relation between the attitudes and intention of students in deciding accounting. In addition of accreditation status, students also acknowledge matters such as the popularity of the higher education institution and job prospects once they graduated. Consideration of these concerns will either strengthen or weaken their dispositions to register in an accounting program.

Research by Spekman \& Carraway (2006) and Ahmad (2015) prove that a highly ranked university reputation/image mostly satisfied students. Therefore, it is essential for higher education institutions to improve their qualities of the program, and provide high-caliber lecturers, good learning environment, effective technology, counseling and academic advising support, and sufficient facilities. These factors form student's perception regarding reputation of higher education institutions. Then, it can affect college their attitudes to major accounting. Based on the explanation above, the hypothesis is as follow:

$\mathrm{H}_{3}$ : The reputation of higher education institution on accounting moderates attitudes toward the students' intentions to major accounting.

\section{Subjective Norms}

Subjective norms are defined as the influence of other referents. They refer to a personal belief about whether specific individuals or groups approve or disapprove the individual performing a specific behavior, and to what extent the individual is motivated to confirm to these other individuals or groups. Subjective norms can be assessed directly or by considering the judgemental beliefs (referent beliefs) which underlie an individual's judgment of subjective norms (Ajzen \& Driver, 2018).

Arifatul Husna et al., (2010) states that subjective norm is a function of beliefs. If a person believes that his or her referents expect that behavior should be performed, then the subjective norm will influence his or her intention to perform that particular behavior. The referents here specify to a group of people who are close to the individual, for instance, family, peers, spouse, close friend, teachers and anyone considered important in one's life.

On the other hand, Lin \& Fawzi (2006) describes subjective norms as a person's perceptions of social pressure to neither perform nor not perform the behavior.It reflects a one's beliefs that other individuals or groups consider they should complete the action (i.e. normative beliefs). These normative beliefs - in combination with a person's motivation to comply with the different referents - determine the prevailing subjective norm regarding the behavior.

Subjective norms are presented in pressure and support of surroundings. This pressure refers to a forceof an individual to perform something regarding the perception of social while support encourage one to carry out something regarding his/her perception. Both pressure and help affect the student's intentions to favoran accounting program. 
Gainau. Job Opportunities, Attitudes,Perceived Behavioral.....

Associated with enrollment in an accounting, support leads to develop learning motivation, as well as pressure generates student's eagerness to learn throughout the semester.

Zandi et al., (2013) find that subjective norm possesses significant influence on the behavioral intention of both male and female college student to enroll in accounting programs. Further, Arifatul Husna et al., (2010) discover the same result where subjective norms significantly affected students' intention in choosing accounting. Parents ominously determine major selection, siblings and friends are also considered as the essential sources in this action. Meddour, Abdo, Majid, Auf, \& Aman (2016) reveal that the family exerted great influence on the choice of career. In terms of enrolling accounting, family and circumstance affects students' intention importantly. Based on the explanation above, the hypothesis is as followed:

$\mathrm{H}_{4}$ : Subjective norms positively affect student intention to major in accounting

\section{Perceived Behavior Controls}

TPB purified TRA by adding behavioral control concept Icek Ajzen \& Thomas J. Madden (1986). Ajzen \& Driver (2018) defines perceived behavior control (PBC) as the perception of how easy or difficult it is to complete behavior, and the presence or absence of resources and opportunities.

In TPB, perceived behavioral controls refer to the degree of control. An individual perceives that one has to engage in a particular behavior. More specifically, control beliefs, the fundamental determinants of perceived behavior control, designate to an individual's opinion regarding the presence or absence of resources and opportunities, and the obstacles and impediments to perform the specific behavior in question (Bobek and Hatfield, 2003).

Perceived behavioral controls had significantly affected students' intention to major in an accounting program (Lin \& Fawzi, 2006). It has shown that accounting students own individual control, which meaningfully impacts them to learn an accounting subject. Arifatul Husna et al., (2010) explain that perceived behavioral controls are reflected in confidence, easiness, education, in-control, and skills and capabilities. These are the factors controlling student's behavior in selecting accounting.

In general, a college student will rethink specific issues before choosing the accounting program, such as resources needed, opportunities in the future, impediments, and obstacles. These four factors are adopted as behavioral control of college students when choosing an accounting program.

Firstly, students will directly examine about what resources are necessary when entering the accounting program, for example, personal confidence, calculators, books, notebooks. Consideration of these things encourage students to prepare themselves earlier to enroll in accounting.

Second is number of obtainable opportunities which can be obtained when they choose an accounting program. Opportunities do not only mean job opportunities, but they also refer to the chances to compete, to organize, and to develop talents as an accounting student. In general, undergraduates will bear in mind whether these opportunities exist, and if they do, these will strengthen their decision to apply in accounting study.

Third and fourth, students will analyze what obstacles and impediments they have to deal with if they choose accounting subject. If challenges and limitations are too 
problematic and crucial to deal with, thus, these situations can discourage them from enlisting themselves as accounting students. Conversely, if students notice that they can overcome every obstacle, learning accounting will not be a burdensome.

To recall, the TPB refers to the specific behavioral choices. Regarding enrollment in an accounting program, PBC suggests how much control an individual believes one is obligated to carry out a specific behavior (e.g., Seeking information related to the accounting program). The positive $\mathrm{PBC}$ will enhance the college student intention to major accounting. Based on the statements above, the hypothesis is as followed:

$\mathrm{H}_{5}$ :Positive perceived behavioral controls significantly affect student intention to major accounting.

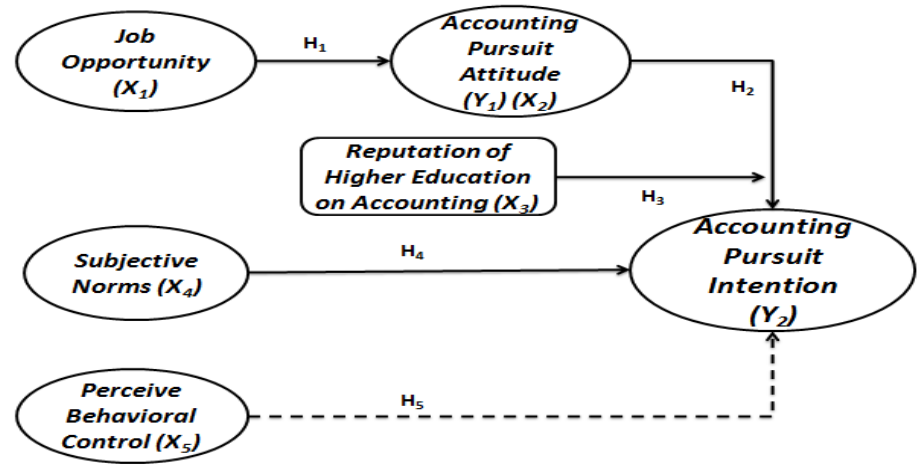

Figure 2. Research Model

\section{RESEARCH METHOD}

This research aims to study factors infuencing the intentions of undergraduates who major the Accounting Program. By the quantitative method, this research uses TPB Model, which modified by Ajzen \& Driver (2018) as well as used by Lin \& Fawzi (2006), Odia \& Ogiedu (2013), and Zandi et al., (2013).

Interviews are adopted to examine the students' learning experiences at private campuses, their perception about reputation of higher education institution about accounting, and their personal and intellectual growth in learning process. The interviews are conducted with 20 college students. All the interviews are transcribed.

\section{Population, Sample, and Sampling Technique}

The population of this research covers all college students (regular college students and on-job college students) who are enlisted in an Accounting Program at private higher education institutions in Manado, and the samples were Economic College of Eben Haezar Manado and at De La Salle Catholic University. The purpose of deciding two campuses as research samples is because of their private statuses, a location right in the city center, and accreditation B. Sampling technique uses Purposive Sampling with criteria: a) students who enrolled from 2012-2017; b) ongoing students.

\section{Operational Definition and Measurement Variable}

The job opportunity is measured by modifying job prospect indicators used by Lin \& Fawzi (2006). It adopts five indicators. These indicators consist of extensive exposures to create business, opportunity to build a personal practice business, 
Gainau. Job Opportunities, Attitudes,Perceived Behavioral.....

High income(salary), high social status, broader employment opportunities. The reputation of higher education institutions on accounting is measured based on seven indicators developed by Ahmad (2015). These indicators involve accreditation status, popularity, student's hometown, having better prospects of employment and higher salary after graduation, reputation, providing a better chance for excellent jobs. Accounting Pursuit Attitudes regulate six indicators used in preceding researches such as by Van Hooft et al. (2004); Hooft, Born, Taris, \& Flier (2006). It uses six questions. These questions are challenging professions, a profession with good professionalism and image, professions with a vital position in a company or organization, the benefits when implementing accounting knowledge, pleasan to ccupations, and the pathways to success.

Subjective Norms gauged instruments which represent referents which refers to those who individually develop a close relationship such as family, close friends, colleagues, lecturers (Arifatul Husna et al., 2010; Bobek and Hatfield, 2003); signicant people (Hooft et al., 2006). It consists of eight indicators. Perceived Behavior Controls uses five indicators as used by Arifatul Husna et al., (2010). It includes confidence, easiness, education, control, and skill and capabilities. Accounting Pursuit Intention evaluates four indicators: time, effort, expectation, and continuance to pursue (van Hooft et al., 2004). This research uses the Likert Scale.

\section{Data Analysis Method}

This research adopts Partial Least Square (PLS). It is a variant-based SEM measuring specific data such as small sample research, missing value, and multicollinearity (Latan and Ghozali, 2012). The test conducted in this research consists of anevaluation of measurement model (outermodel), evaluation of structural model (innermodel), and evaluation of overall (overall fitindex). In the model evaluation, measurement is carried out with pretest to existing indicators, validity test, and reliability test. In the structural model evaluation, test on prediction power is seen from R-Squares, and hypothesis tests are seen from t-statistic value. Evaluation of the overall model is conducted by employing goodness of criteria developed by Tenenhaus et al., (2004) known as GoF index. This index is designed to assess the measurement and structural models. For this explanation, GoF index is calculated from square root average grade of communality index and an average of R-squares:

$$
\boldsymbol{G O F}=\sqrt{\overline{\mathbf{C O M}} \times \overline{\boldsymbol{R}^{2}}}
$$

Recommended community value is 0,50 (Fornel dan Larcker 1981) and value of R-Suare small $=0,02$, Medium $=0,13$, and Large $=0,26$ (Cohen, 1988).

\section{RESULTS AND DISCUSSION}

Demographic data of this research is shown in Table 2.

Table 2. Respondent Demographic Data

\begin{tabular}{llcc}
\hline & Respondent Demographic & Total & $\%$ \\
\hline \multirow{2}{*}{ Sex } & Male & 32 & $32 \%$ \\
& Female & 68 & $68 \%$ \\
\multirow{3}{*}{ Age } & $17-19$ years old & 23 & $23 \%$ \\
& $20-22$ years old & 58 & $58 \%$ \\
\multirow{2}{*}{ Higher } & $23-25$ years old & 14 & $14 \%$ \\
& More than 25 years old & 1 & $1 \%$ \\
& Economic College of Eben Haezar Manado & 73 & $73 \%$
\end{tabular}




\begin{tabular}{|c|c|c|c|}
\hline $\begin{array}{l}\text { Education } \\
\text { Institution }\end{array}$ & De La SalleCatholic University & 46 & $46 \%$ \\
\hline \multirow{3}{*}{$\begin{array}{l}\text { Year } \\
\text { College }\end{array}$} & $2013-2014$ & 40 & $40 \%$ \\
\hline & $2015-2016$ & 43 & $43 \%$ \\
\hline & 2017 & 17 & $17 \%$ \\
\hline \multirow{2}{*}{ Class } & Regular & 76 & $76 \%$ \\
\hline & On-Job & 24 & $24 \%$ \\
\hline
\end{tabular}

Table2 figures demographic data of respondents based on sex (mostly are women i.e.68 college students and the rest are men i.e.32 college students). Meanwhile, the age variable is dominated by age between 20 to 22 years old, i.e...58 students. Students who enrolled in 2013-2014 were the highest, i.e., 40 students (40\%) and most of whom are in regular class (76 students) and the rest are an on-job students.

\section{Descriptive Statistics of Object of Research}

Indicators of descriptive statistics are explained in terms of Minimum, Maximum, Mean and Standard Deviation. It is shown in Table 3.

Table 3. Descriptive Statistics Indicators of Variabel

\begin{tabular}{|c|c|c|c|c|c|c|}
\hline Indicator & Statement & Total & Min & Max & Mean & $\begin{array}{l}\text { Deviation } \\
\text { Standar }\end{array}$ \\
\hline JO1 & $\begin{array}{l}\text { Extensive exposure to create your own } \\
\text { business. }\end{array}$ & 100 & 1 & 5 & 4,47 & 0,68 \\
\hline $\mathrm{JO} 2$ & $\begin{array}{l}\text { Opportunity to build a personal practice } \\
\text { business }\end{array}$ & 100 & 2 & 5 & 4,35 & 0,59 \\
\hline JO3 & Income (salary) is high in the future & 100 & 1 & 5 & 4,29 & 0,75 \\
\hline $\mathrm{JO} 4$ & High social status & 100 & 2 & 5 & 3,71 & 0,80 \\
\hline JO5 & Broader employment opportunities & 100 & 1 & 5 & 4,34 & 0,75 \\
\hline \multicolumn{5}{|c|}{ Average of Job Opportunity } & 4,23 & 0,71 \\
\hline RHEI1 & $\begin{array}{l}\text { Accreditation status of campus is considered } \\
\text { before choosing the accounting program }\end{array}$ & 100 & 1 & 5 & 3,05 & 1,02 \\
\hline RHEI2 & $\begin{array}{l}\text { Thecampus is locally known and } \\
\text { recognized by many people }\end{array}$ & 100 & 1 & 5 & 2,84 & 1,01 \\
\hline RHEI3 & $\begin{array}{l}\text { Thecampus is valued by college student } \\
\text { hometown }\end{array}$ & 100 & 1 & 5 & 2,60 & 0,97 \\
\hline RHEI4 & $\begin{array}{l}\text { The campus has better prospects of } \\
\text { employmentand higher salary after graduation }\end{array}$ & 100 & 1 & 5 & 3,81 & 0,92 \\
\hline RHEI5 & $\begin{array}{l}\text { The degrees from thecampus are more } \\
\text { Prestigious }\end{array}$ & 100 & 1 & 5 & 3,73 & 0,97 \\
\hline RHEI6 & $\begin{array}{l}\text { Confidence that the degree from the campus } \\
\text { will provide a better chance for a good job } \\
\text { afterGraduation }\end{array}$ & 100 & 1 & 5 & 3,24 & 0,93 \\
\hline RHEI7 & $\begin{array}{l}\text { The quality of the campusis not the main issue } \\
\text { to be considered }\end{array}$ & 100 & 1 & 5 & 2,97 & 1,10 \\
\hline \multicolumn{5}{|c|}{ Average of Reputation of Higher Education Institution } & 3,17 & 0,99 \\
\hline APA1 & Challenging profession & 100 & 2 & 5 & 4,35 & 0,71 \\
\hline APIA2 & $\begin{array}{l}\text { Profession with good professionalism and } \\
\text { image }\end{array}$ & 100 & 3 & 5 & 4,45 & 0,59 \\
\hline APA3 & $\begin{array}{l}\text { Profession with an important position in a } \\
\text { company ororganization }\end{array}$ & 100 & 1 & 5 & 4,34 & 0,72 \\
\hline APA4 & $\begin{array}{l}\text { The benefits when implementing accounting } \\
\text { knowledge }\end{array}$ & 100 & 1 & 5 & 4,48 & 0,62 \\
\hline APA5 & Pleasant profession & 100 & 2 & 5 & 3,91 & 0,71 \\
\hline APA6 & The way to success & 100 & 2 & 5 & 4 & 0,76 \\
\hline
\end{tabular}


Gainau. Job Opportunities, Attitudes, Perceived Behavioral.....

Average of Attitudes

SN1 Family supports and encourages me

SN2 Close friends support and encourage me

SN3 Colleagues support and encourage me

SN4 Concern when family agrees / disagrees

SN5 Concern when close friends agree / disagree

SN6 Concern when colleagues agree / disagree

Average of Subjective Norms

PB1 Personal confidence

PB2 Easy

PB3 Right education

PB4 Full control

PB5 Skills and capabilities

PB6 Difficulty or distress learning

Average of Perceived Behavior Controls

API1 Intention to devote much time to look for information about the accounting program.

API2 Intention to make an effort to enroll in API3 The expectation to get the benefits throughout

API4

Continue to learn (deepen) accounting knowledge

$\begin{array}{ccccc}100 & 1 & 5 & 4,25 & 0,69 \\ 100 & 1 & 5 & 3,55 & 1,22 \\ 100 & 1 & 5 & 3,25 & 1,13 \\ 100 & 2 & 5 & 3,69 & 0,87 \\ 100 & 1 & 5 & 3,30 & 1,01 \\ 100 & 1 & 5 & 3,25 & 0,98 \\ & & & 3,37 & 1,05 \\ 100 & 2 & 5 & 4,15 & 0,68 \\ 100 & 1 & 5 & 2,95 & 0,99 \\ 100 & 2 & 5 & 4,11 & 0,72 \\ 100 & 2 & 5 & 3,85 & 0,77 \\ 100 & 2 & 5 & 3,89 & 0,75 \\ 100 & 1 & 5 & 2,72 & 1,03 \\ & & & 3,61 & 0,82 \\ 100 & 2 & 5 & 3,97 & 0,74 \\ & & & & \\ 100 & 1 & 5 & 3,92 & 0,85 \\ & & & & \\ 100 & 2 & 5 & 4,18 & 0,77 \\ & & & & \\ 100 & 1 & 5 & 3,42 & 0,92 \\ & & & 3,87 & 0,82\end{array}$

Average of Intentions

Source: Primary Data

Mean of Job Opportunity (JO) shows 4.23 categorized as high. Five indicators in this research display the high scores depicting undergraduates who study accounting to have the similar perception which provides many job opportunities in the future. In general, students respond quite positively about the employment availability in accounting field. Four of the respondents emphasized that the work availability in accounting is one of the main factors in influencing students' decisions in applying to higher education. One of a student from on-job class claimed that:

'I chose accounting program because it provides wide job opportunities and it supports me in my current job in a bank.' A respondent from regular class stated that: 'I chose accounting program because I will manage my parents'business. Accounting has the opportunity to run a business well'.

Total Mean of Reputation of Higher Education Institution on Accounting (RHEI) is 3.17 categorized as "moderate" (average). Two indicators are high and five indicators are average. These indicators figures that students are independent enough to consider reputation of higher education institution on accounting when majoring in accounting. The students are asked to rate the importance of 7 indicators of their decision to study in an accounting program. They responded that the factor selected as being most important was the better prospects of employment and a higher salary. This factor was followed by the campus popularity (locally known and recognized by many people). One of the respondents from regular class stated as follows:

"I chose accounting program at my current campus because it has a good reputation in the society. Most of my surroundings know it.' A college student from an on-iob class claimed that: 'I chose this campus because of the direction of God. At the former campus, I was bullied by seniors. They slapped me several times at that time. So, I decided to move in this 
campus because it has a distinctive character (weekly worship) and a good reputation. 'However, most of the respondents were not consider campus reputation when choosing to account. A respondent from regular class stated that 'When I was looking for the campus, I was not thinking about campus reputation, not at all. I just thought about how much the tuition fee and campus location because my parents were unable to pay the high tuition fee and transportation cost".

The total means of Accounting Pursuit Attitudes (APA) is 4.25 categorized as high. Six indicators are excellent. It describes that accounting students have very positive perceptions regarding the accounting. Respondents reported that accounting programis useful and they enjoy it. The reasons most often cited as 'agree' by college students were the benefits in implementing accounting knowledge ' $(\mathrm{M}=$ 4.48),'professions with good professionalism and image' $(M=4.45)$, 'challenging profession' $(\mathrm{M}=4.35)$ and 'profession with an important position in a company ororganization' $(\mathrm{M}=4.34)$.

Most of the respondents in the interviews highlighted that accounting is essential everywhere, this is why they selected it. Their opinions lend credence to the view that students are aware of the kind of advantages in which they will receive from the accounting program. Comments from a college student in an interview included, as follows:

'When I was in high school I received an accounting subject and I liked it because it is interesting. I can implement it everywhere, and I'lI chose accounting program because I wanted to continue the lessons I had learned in the highs chool'.

The total means of Subjective Norms in choosing an Accounting Program is 3.37, which shows the average (moderate) where one indicator is high and five indicators are average. It depicts that students obtain sufficient support and motivation from surroundings when choosing Accounting. Three participants described that their parents's advice and workplace requirements are the main factors to apply in accounting. However, the rest of the respondents claimed that the decision to study accounting was theirs. Parents and surroundings did not influence them. One of the interviewees from the regular class described: "I enrolled in the other program but my parents advised me to enroll in an accounting program because they wanted me to work as a banker".

The total means of Perceived Behaviour Control (PBC) in choosing Accounting is 3.61 classified as "moderate or average. Four of the six indicators are categorized as high, while two indicators are average. It summarizes that accounting students have adequate confidence, easiness, capabilities, and difficulties in studying accounting.

The undergraduates who participated in this study reported that there were several factors that control them to register in accounting. The reasons most often cited as 'totally agree' by them were 'personal confidence' $(\mathrm{M}=4.15)$, 'appropriate education' $(\mathrm{M}=4.11)$. These two factors were represented by their behavior in choosing accounting program. Further, the reasons most often cited as 'totally not agree' by students were 'difficulties or distress learning' $(M=2,72)$ and 'easiness' $(M=2,95)$. These represent personal behavior control of students to not enlist accounting as 
Gainau. Job Opportunities, Attitudes,Perceived Behavioral.....

their study focus. During the interview sessions, several college students reported that sometimes they encounter difficulties in understanding the accounting cycle. They are aware that it requires high analytical power and a high level of accuracy. A student claimed that 'The difficulties in the accounting program encourage me to be more active and study hard.'.

The total mean of Accounting Pursuit Intentions (API) is 3.87 categorized as high. Three of the four indicators are high on average, while one indicator is moderate. It means that accounting students have an optimistic willingness to major accounting.

The total mean of six variables used in this research shows excellent score. Three variables categorized as high are, i.e., Job Opportunity (4.23), Accounting Pursuit Attitudes (4.25) and Accounting Pursuit Intention (3.87). Meanwhile, the three variables are moderate, i.e., Reputation of Higher Education Institution on Accounting (3.17), Subjective Norms (3.37), and Perceived Behaviour Control (3.61).

It is agreeable that when enrolling in an accounting program, students tend to be inconsiderate about the reputation of higher education institutions on accounting, subjective norms, and perceived behavior control. Otherwise stated, three variables shown by moderate core are not prioritized. Therefore, it can be summarized that the six variables used in this research support research model.

The standard deviation of the six variables is excellent, which is less than the average score of each indicator. Hence, it is regarded as data is well-distributed, which its variance difference is low.

\section{Outer Model (Measurement Model Fit)}

Validity Test

Structural Equation Model (SEM) provides a formula for validity and reliability tests. The common method in SEM when measuring confirmatory factor analysis is by using MultiTrait-MultiMethod (MTMM). It measures convergent validity and discriminant (Campbell and Fiske, in Latan and Ghozali 2012, 78). In SmartPLS 3.0, a reflective indicator of validity test requires loading factor for every construct indicator $>0.7$, and average variance extracted (AVE) is $>0.5$. However, in previous research, the loading factor value was acceptable between 0.5 and 0.6 (Chin 1998 in Latan and Ghozali 2012, 78). Discriminant validity was measured by determining the cross-loading of any variable. It requires $>0.7$. The initial indicator of validity test is as follow:

Table 4. Validity Test of Indicators (Continue)

\begin{tabular}{ccccc}
\hline Indicator & $\begin{array}{c}\text { Loading factor }> \\
0,70\end{array}$ & $\begin{array}{c}\text { Cross } \\
\text { loading }>0,70\end{array}$ & AVE & Validity \\
\hline JO1 & 0,749 & 0,75 & & Valid \\
JO2 & 0,792 & 0,79 & 0,627 & Valid \\
JO3 & 0,762 & 0,76 & & Valid \\
JO5 & 0,860 & 0,86 & & Valid \\
RHEI4 & 0,888 & 0,89 & 0,716 & Valid \\
RHEI6 & 0,801 & 0,80 & & Valid \\
APA2 & 0,781 & 0,78 & \multirow{2}{*}{0,727} & Valid \\
APA3 & 0,866 & 0,87 & Valid \\
APA4 & 0,906 & 0,91 & & Valid \\
SN2 & 0,744 & 0,74 & & Valid \\
SN3 & 0,731 & 0,73 & & Valid \\
SN4 & 0,796 & 0,80 & 0,624 & Valid \\
SN5 & 0,877 & 0,88 & & Valid \\
SN6 & 0,793 & 0,79 & & Valid \\
\hline
\end{tabular}




\begin{tabular}{lllll}
\hline PBC1 & 0,866 & 0,87 & & Valid \\
PBC3 & 0,874 & 0,87 & 0,705 & Valid \\
PBC5 & 0,776 & 0,78 & & Valid \\
DPI1 & 0,701 & 0,70 & & Valid \\
DPI2 & 0,862 & 0,86 & 0,680 & Valid \\
DPI3 & 0,903 & 0,90 & & Valid \\
\hline
\end{tabular}

Source: Data output software SmartPLS 2.0 M3.

Table 4 displays AVE score $>0.5$ which means more than $50 \%$ indicator variance is explainable and clarified. Therefore, discriminant and convergent validity requirements are fulfilled.

Reliability Test

The measurement model is applied to evaluate there liability of the construct. The reliability test measures the accuracy, consistency, and correctness of construct. It uses Cronbach's Alpha and Reliability Composite, which > 0.70 (Ghozali and Latan 2015).

Table 5. Result of Reliability Test

\begin{tabular}{cccc}
\hline Latent Variable & $\begin{array}{c}\text { Composite } \\
\text { Reliability } \geq 0,70\end{array}$ & $\begin{array}{c}\text { Cronbach's } \\
\text { Alpha }\end{array}$ & Conclusion \\
\hline JO & 0,870 & 0,870 & Reliable \\
RHEI & 0,834 & 0,834 & Reliable \\
APA & 0,889 & 0,889 & Reliable \\
SN & 0,892 & 0,852 & Reliable \\
PBC & 0,877 & 0,877 & Reliable \\
DPI & 0,863 & 0,863 & Reliable \\
\hline
\end{tabular}

Source: Data output software SmartPLS 2.0 M3.

Table 5 displays that all variables possess Composite Reliability and Cronbach Alpha $>0.70$, meaning that six variables in the research model are trust worthy.

Inner Model (Structural Model Fit).

In the PLS model, the initial step is to calculate the R-Square of the endogenous latent variable. It is the predictive power of the structural model. R-Square measures and explains the effect of a particular exogenous latent variable towards endogenous latent variable. In this research, R-Square varies $(0.75,0.50$, and 0.25$)$, which it figures that the model is robust, moderate, and weak. Its variety represents the value of construct variance of the model.

The model evaluation utilizes significant value to estimate the impacts among variables. Assessment of the structural model is associated with the hypothesized variable. It adjusts the relationship among variables and their significances. The result of the test is shown in Table 6.

Table 6. Structural Model Fit

\begin{tabular}{lcc}
\hline \multicolumn{1}{c}{ Variabel Laten } & R Square \\
\hline Job Opportunity (JO) & \\
Accounting Pursuit Attitudes (APA) & 0,521 & \\
Reputation of Higher Education (RHEI) & & 0,330 \\
Subjective Norms (SN) & \\
Perceived Behavior Control (PBC) & \\
Accounting Pursuit Intentions (API) & \\
\hline Data output software SmartPLS 3.0, 2018.
\end{tabular}


Gainau. Job Opportunities, Attitudes,Perceived Behavioral.....

Table 6 presents R-Square of Accounting Pursuit Attitudes (APA) as Y1 and Accounting Pursuit Intentions (API) as Y2. R-square of APA is 0.521, which means moderate. Meanwhile, R-Square of API is 0.330, which means weak.

Table 7. Result of Structural Model Fit

\begin{tabular}{ccccc}
\hline \multirow{2}{*}{ Hypotheses } & \multicolumn{1}{c}{ Path } & $\begin{array}{c}\text { Total } \\
\text { Effects }\end{array}$ & T-statistics $\geq 1,96$ & Conclude \\
\hline H1 & JO $\rightarrow$ APA & 0,722 & 8,610 & Significant \\
H2 & APA $\rightarrow$ API & 0,216 & 2,313 & Significant \\
H3 & RHEI*APA $\longrightarrow$ API & $-0,200$ & 0,909 & No Significant \\
H4 & SN $\longrightarrow$ API & 0,119 & 1,404 & No Significant \\
H5 & PBC $\longrightarrow$ API & 0,317 & 3,199 & Significant \\
\hline \multicolumn{2}{l}{ Source: Data output software SmartPLS 2.0. }
\end{tabular}

\section{CONCLUSION}

Based on the hypothesis test mentioned above, it is confirmed that students' perceptions of job opportunity hold a positive significant in influence on Accounting Pursuit Attitudes (APA). Job opportunity refers to employment opportunities to work in the accounting field. The test result defines that the perception of students about a job opportunity in the accounting field will develop their attitudes in pursuing an accounting program. Both negative perception and positive perception inspire students' attitudes in majoring an accounting programs. The perception of such as the accounting profession is scary, complex, and difficult, is believed as the tools to increase their creativity, cognitive ability, level of accuracy, and diligence. Moreover, the positive perception such as an accountant profession is interesting, challenging, promising, high salary, will advocate students to choose an accounting program. Meaning, even though students have undesirable perceptions towards accounting, it did not change their decision to choose an accounting program.

The findings confirm with studies similar to Gul et al. (1989), Mauldin, Crain, \& Mounce (2000), Kim et al., (2002), Lin \& Fawzi (2006), Odia \& Ogiedu (2013), (Zandi et al., 2013), and Widowati \& Surjawati (2015).These authors address that the job opportunity in accounting induces students' attitudes to prefer accounting rather than other program. This proves that students decide to pursue their education in accounting based on their personal perspective associated with a job opportunity in the accounting field, even though it is complex. The future advantages and outcomes are believed to be balanced for those who willingly register in accounting major. Undergraduate students prefer to define job opportunity in accounting as vast in which their intention is encouraged during selecting the subject. Current study empirically indicates that employment availability will modify students' behavior to either apply accounting as their learning goal or not.

Second hypothesis - this study discovers that Accounting Pursuit Attitudes (APA) of students influence their intention to study accounting (API). Its t-statistical so strengthens it, which is 2.313 , more than the parameter $(2.313>1.96)$. This result is a continuation of the impact of the first hypothesis (H1). Students' attitudes affects their willingness to major in accounting. In other words, the positive and negative attitudes possessed will either extend or decrease their desire to learn accounting. 
The result corroborates the findings of Gul et al (1989), Mauldin et al., (2000), Kim et al., (2002), Lin \& Fawzi (2006), Odia \& Ogiedu (2013), Zandi et al.(2013), and Widowati \& Surjawati (2015) that state students' perspective impressed their ambition to aim for aqualification in accounting degree. Therefore, this research empirically proves that students' point of view positively determines their desire to be accounting students.

The third hypothesis - the study findings justifies that reputation of higher education institution does not alter their attitudes to select an accounting program. Alternatively, students determine their own intention to enroll in accounting by their personal attitudes (personal perception). Ittentatively validates that the reputation of higher education institutionis not a crucial factor regarded by an individual when deciding to study accounting. Some respondents were asked to acknowledge the most indicative factors which they think of during the program selection process. Most of them claimed that the campus reputation is not an essential factor, but the tuition fee. However, Sathapornvajana \& Watanapa, (2012) and Ahmad (2015) discover the opposite outcome.

Fourth hypothesis - subjective norms (SN) have not entirely developed students' intention to learn in an accounting program (API). Meaning, the decision to study accounting is not affected by parents and their surroundings, instead of by their perception (attitude). It also indicates that willingness to learn accounting is not because of social pressure, family, and co-workers but self-encouragement. The fourth hypothesis is not supported. The result is opposite to the findings of Lin \& Fawzi (2006), Odia \& Ogiedu (2013), Zandi et al, (2013), and Dr Ahmad Nahar Al-Rfou (2013).

This result affirms to be inconsistent with the researcher's initial hypothesis (curiosity). Some of the interviewees describe their obstacles throughout the semester. Comment of a student from a regular class, as follows:

'Lecturers applied various rules in the learning process that tend to harm college student. Sometimes lecturers also treat college student arbitrarily, eventhough we pay tuition fees every month. For some lecturers, we have to understand their mood and this greatly affects our motivation throughout the learning process'.

This showed that the lecturers' behavior have significant effect on students' learning motivation. A respondent of an on-job class describes that 'I was very difficult to manage the time between my assignments and my office work'. Four respondents acknowledge that their obstacle in the learning process was the difficulties in some subjects, but instead they ensure it as the way which encourages them to study hard.

The fourth hypothesis is not supported. Therefore, students who experience declines in enthusiasm in the learning process are not caused by study program's choice but because of seasonal factors. It can be the feedback for lecturers to update their teaching methods/strategies, and also their behavior to motivate college students during the learning process.

Fifth hypothesis - Perceived Behavior Control (PBC, or personal efficacy) has unquestionably impacted the students' desires to acquire a degree in accounting. It was in line with Lin \& Fawzi (2006), Arifatul Husna et al. (2010) findings. It means that 
Gainau. Job Opportunities, Attitudes,Perceived Behavioral.....

accounting students possess personal control when choosing to study accounting, which influences their intention to enroll. It analytically signifies that students are aware of their chance and obstacles in the future. Therefore, personal confidence, education, and capability are required to motivate students to pursue careers in accounting areas.

The objective of students choosing an accounting program was due to the consideration of the resources that must be prepared, opportunities, and obstacles. Review of these will form their confidence, belief, and ability to study in the accounting program.

Overall, this research finds that the intention of students to choose an accounting program is determined by iob opportunity, attitude, and perceived behavior control. Meanwhile, subjective norms and reputation of higher education institution on accounting do not significantly affected college students's intentions to continue study in higher education majoring in an accounting program.

Overall Fit Index (Goodness of Fit)

For GoF index is calculated from the square root of the average value of commonality index and average R-squares:

$$
G O F=\sqrt{C \overline{O m} \times \overline{R^{2}}}
$$

Recommended communality value is 0,50 (Fornel dan Larcker 1981) and the value of $\mathrm{R}$-Square small $=0,02$, Medium $=0,13$, and Large $=0,26$ (Cohen 1988). GoF small $=$ 0,10 , GoF medium $=0,25$, GoF large $=0,36$. Communality value is considered equivalent to AVE because either communality and AVE are used to measure the validity of construct. The calculation of GoF Index is shown below:

$$
\begin{aligned}
& G O F=\sqrt{0,680 \times 0,343} \\
& =0,483
\end{aligned}
$$

The evaluation outcome of $\mathrm{GoF}$ is $0,483>0,36$. It generally indicates model which holds strong prediction power.

\section{CONCLUSION}

College student perception regarding job opportunity (JO) in accounting field positively infuenced accounting pursuit attitudes (APA). Further, both accounting pursuit attitudes (APA) and perceived behavior control (PBC) excellently develop student's willingness to study accounting (API). On the other hand, the reputation of higher education institutions do not moderate students' attitude toward their intention to choose an accounting program. It means college students do not consider the reputation of higher education institution on accounting as the main factor infuencing their decision to major an accounting study. Moreover, the study indicates that subjective norms contribute no crucial effects on college students regarding their will in pursuing adegree in an accounting study program. Students' decisions to choose accounting program is not in influenced by their parents, relatives, and friends.

\section{Research Implications}

It is essential to explain the benefits and the job opportunity in accounting 
fields to potential students when campus goes to highs chools. Lecturers need to include the temporary issues of accounting to remove the negative perception regarding the accounting field.

Management of the accounting department is obligated to re-design the learning curriculum, thus, it can drive students to compete and having fun throughout the learning process. It can boost positives perception (attitude) regarding the accounting program to society. Since accounting courses still follow a strict curriculum, less innovation, creativity, and autonomy, these will attach a negative image to accounting education.

Educational services play a central role in students's lives, and it requires them to have vast amounts of motivation and intellectual skills to attain their goals. Lecturers have to pay attention on how they should treat students because it will have impact on students's learning motivation.Therefore, educators should include educational characters in the provision of material to boost their learning motivation. It is insufficient for lecturers to be knowledgeable. Therefore, they should also have the ability to impart knowledge and be willing to help a college student. Furthermore, lecturers must update their learning methods to maintain students' interests in learning.

\section{Limitation and Suggestion}

The sample needed in this study is college students in the first semester, however, due to inadequate samples, this research involved only senior college students. Therefore, further research must include more colleges and campuses to achieve sufficient samples. The software of data processing can only run $\leq 100$ samples; consequently some samples were excluded from these analyzes. This situation limits the researcher ability to examine the existing data of research. Therefore, further research is suggested to use a better program which analyzes more significant samples such as LISREL and AMOS.

\section{REFRENCES}

Ahmad, S. Z. (2015). Evaluating Student Satisfaction of Quality at International Branch Campuses. Assessment and Evaluation in Higher Education, 40(4), 488-507. https://doi.org/10.1080/02602938.2014.925082

Ajzen, I., \& Driver, B. L. (2018). Application of the Theory of Planned Behavior to Leisure Choice. Journal of Leisure Research, 24(3), 207-224. https://doi.org/10.1080/00222216.1992.11969889

Arifatul Husna, M. A., Zainol, B., Zakiyah, S., \& Adura, A. (2010). Predicting entrepreneurship intention among Malay university accounting students in Malaysia. UNITAR E-Journal, 6(1), 1-10. Retrieved from http://search.ebscohost.com/login.aspx?direct=true $\& \mathrm{db}=\mathrm{a} 9 \mathrm{~h} \& \mathrm{AN}=51444630 \&$ site $=\mathrm{eh}$ ost-live

Bae, H. S., \& Kang, S. (2008). The Influence of Viewing an Entertainment-Education Program on Cornea Donation Intention: A Test of the Theory of Planned Behavior. Health Communication, 23(1), 87-95. https://doi.org/10.1080/10410230701808038 
Gainau. Job Opportunities, Attitudes,Perceived Behavioral.....

Bobek, D. D., and R. C. Hatfield. 2003. An Investigation of The Theory of Planned Behavior and The Role of Moral Obligation in Tax Compliance. Behavioral Research In Accounting, Volume 15, 2003.

Cohen, J. 1988. Statistical Power Analysis for the Behavioral Sciences. Hillsdale. New Jersey: Lawrence Erlbaum Associates.

Dr Ahmad Nahar Al-Rfou, D. A. N. A.-R. (2013). Factors that Influence the Choice of Business Major Evidence from Jordan. IOSR Journal of Business and Management, 8(2), 104-108. https://doi.org/10.9790/487x-082104108

Gul, F. A. et al. 1989. Factors Influencing Choice Of Discipline Of Study - Accountancy, Engineering, Law and Medicine, Accounting and Finance, 29, pp. 93-101.

Hooft, E. A. J. Van, Born, M. P., Taris, T. W., \& Flier, H. Van der. (2006). Ethnic and Gender Differences in Applicants' Decision-Making Processes: An application of The Theory of Reasoned Action. International Journal of Selection and Assessment, 14(2), 156-166. Retrieved from http://search.ebscohost.com/login.aspx?direct=true $\& \mathrm{db}=$ eoah $\& A N=24338136 \&$ site $=e$ host-live

Hsiao, J., \& Nova, S. P. de C. C. (2016). Generational Approach to Factors Influencing Career Choice in Accounting. Revista Contabilidade \& Finanças, 27(72), 393-407. https://doi.org/10.1590/1808-057x201602980

Icek Ajzen, \& Thomas J. Madden. (1986). Prediction of Goal-Directed Behavior: Attitudes , Intentions, and Perceived Behavioral Control. Journal of Experimental Social Psychology, 474, 453-474.

Kim, D., Markham, F. S., \& Cangelosi, J. D. (2002). Why Students Pursue the Business Degree: A Comparison of Business Majors Across Universities. Journal of Education for Business, 78(1), 28-32. https://doi.org/10.1080/08832320209599694

Latan, H.and I. Ghozali, 2012.Konsep, Teknik dan Aplikasi SmartPLS 2.0 M3 untuk Penelitian Empiris.Semarang: Badan Penerbit Universitas Diponegoro.

Lin, T., \& Fawzi, L. (2006). Students' Beliefs, Attitudes and Intentions to Major in Accounting. Accounting Education, 15(2), 167-187.

Mauldin, S., Crain, J. L., \& Mounce, P. H. (2000). The Accounting Principles Instructor \{ltextquoteright $\}$ s Influence on Students $\{$ |textquoteright $\}$ Decision to Major in Accounting. Journal of Education for Business, 75(3), 142-148.

Meddour, H., Abdo, A. A. M., Majid, A. H. A., Auf, M. A. A., \& Aman, A. M. (2016). Factors Affecting Career Choice Among Undergraduate Students in Universitas Indonesia. International Journal of Economic Perspectives, 10(4), 630-644.

Odia, J. O., \& Ogiedu, K. O. (2013). Factors Affecting the Study of Accounting in Nigerian Universities. Journal of Educational and Social Research, 3(3), 89-96. https://doi.org/10.5901/jesr.2013.v4n3p89

Saemann, G. P., \& Crooker, K. J. (1999). Student Perceptions of the Profession and its Effect on Decisions to Major in Accounting. Journal of Accounting Education, 17(1), 1-22. https://doi.org/10.1016/S0748-5751(99)00007-X

Sathapornvajana, S., \& Watanapa, B. (2012). Factors Affecting Student's Intention to Choose IT Program. Procedia Computer Science, 13, 60-67. https://doi.org/10.1016/j.procs.2012.09.114

Scott Hunsinger, D., \& A. Smith, M. (2017). Factors that Influence Information Systems Undergraduates to Pursue IT Certification. Journal of Information Technology 
Education: Research, 7(November), 247-265. https://doi.org/10.28945/188

Spekman, R. E., \& Carraway, R. (2006). Making the Transition to Collaborative BuyerSeller Relationships: An Emerging Framework. Industrial Marketing Management, 35(1), 10-19. https://doi.org/10.1016/j.indmarman.2005.07.002

Tenenhaus, M., Amato, S., and Esposito Vinzi, V. 2004. A Global Goodness of Fit Index for PLS Structural Equation Modeling. Proceedings of the XLII SIS Scientic Meeting, Vol. Contributed Papers, CLEUP, Padova, pp. 739-742.

Zandi. G., B. Naysary. and S. S. Kwan. 2013. The Behavioral Intention of Malaysian College Student Toward Accounting Discipline. Accounting and Management Information Systems Vol. 12, No. 3, pp. 471-488.

van Hooft, E. A. J., Born, M. P., Taris, T. W., van der Flier, H., \& Blonk, R. W. B. (2004). Predictors of Job Search Behavior Among. Personnel Psychology, 57, 25-59.

Widowati, A. I., \& Surjawati, S. (2015). Studi Tentang Keputusan Memilih Jurusan S1 Akuntansi (Studi Empiris Pada Mahasiswa Program Studi S1 Akuntansi Universitas Semarang). Jurnal Dinamika Sosial Budaya, $17(1), \quad 1$. https://doi.org/10.26623/jdsb.v17i1.498 